\title{
Article \\ Effect of Stem Snapping on Aspen Timber Assortment Recovery in Hemiboreal Forests
}

\author{
Linda Čakša ${ }^{1}$, Silva Šēnhofa ${ }^{1}\left(\mathbb{D}\right.$, Guntars Šṇepsts ${ }^{1}$, Didzis Elferts ${ }^{1,2}{ }^{\mathbb{D}}$, Līga Liepa ${ }^{3}$ and Āris Jansons ${ }^{1, *(\mathbb{D})}$ \\ 1 Latvian State Forest Research Institute, Silava, Rīgas Street 111, LV-2169 Salaspils, Latvia; \\ linda.caksa@silava.lv (L.Č.); silva.senhofa@silava.lv (S.Š.); guntars.snepsts@silava.lv (G.Š.); \\ didzis.elferts@lu.lv (D.E.) \\ 2 Faculty of Biology, University of Latvia, Jelgavas Street 1, LV-1004 Rīga, Latvia \\ 3 Forestry Faculty, Latvia University of Life Sciences and Technologies, Liela 2, LV-3001 Jelgava, Latvia; \\ liga.liepa@llu.lv \\ * Correspondence: aris.jansons@silava.lv
}

Citation: Čakša, L.; Šēnhofa, S.; Šnepsts, G.; Elferts, D.; Liepa, L.; Jansons, A. Effect of Stem Snapping on Aspen Timber Assortment Recovery in Hemiboreal Forests. Forests 2021, 12, 28. https://doi.org/ $10.3390 /$ f12010028

Received: 16 November 2020 Accepted: 24 December 2020 Published: 28 December 2020

Publisher's Note: MDPI stays neutral with regard to jurisdictional claims in published maps and institutional affiliations.

Copyright: () 2020 by the authors. Licensee MDPI, Basel, Switzerland. This article is an open access article distributed under the terms and conditions of the Creative Commons Attribution (CC BY) license (https: / / creativecommons.org/ licenses/by/4.0/).

\begin{abstract}
Post-disturbance salvage logging mitigates economic loss after windthrow, and the value of salvaged timber is strongly linked to its quality and dimensions. We studied the occurrence of wind-induced damage of aspen in the hemiboreal forests of Latvia based on data from the National Forest Inventory and additional measurements. Individual tree data from three re-measurement periods were linked to follow a tree condition (live, broken, uprooted) and to link tree characteristics to a respective snag. Three linear models were developed to assess factors affecting the snapping height. An assortment outcome was calculated for undamaged and salvaged trees using the bucking algorithm, and timber value was calculated at three price levels. Wind-induced damage occurred for $3.4-3.6 \%$ of aspen trees, and among these, $45.8-46.6 \%$ were broken. The mean height of the broken trees was $27.3 \pm 0.9 \mathrm{~m}$, and it was significantly higher (both $p<0.01$ ) compared to the height of undamaged and uprooted trees. The tested models indicated tree height as the main explanatory variable for relative snapping height, with higher trees having a lower point of the stem breakage. The other significant factor was the forest type group, indicating that trees growing on dry mineral soils had lower relative snapping height than trees growing on drained mineral soils. Stem breakage significantly $(p<0.001)$ reduced the volume of assortments, as compared to the volume of undamaged trees. Relative volume loss of sawlogs showed a logarithmic trend with a steep increase up to snapping height of $6 \mathrm{~m}$, and it correlated tightly $(\mathrm{r}=0.83, p<0.001)$ with relative value loss of the total stem. Timber value loss had a strong, positive relation to tree diameter at breast height and fluctuated by $0.4 \%$ among different price levels. The mean volume reduction was $37.7 \%$ for sawlogs, $11.0 \%$ for pallet blocks, and $8.9 \%$ for technological wood.
\end{abstract}

Keywords: wind damage; stem breakage; Populus tremula; timber value reduction; windthrow

\section{Introduction}

European forests encounter increased severity and frequency of natural disturbances [1] that have substantial negative socio-economic consequences [2,3], especially in regions that are highly dependent on the forest sector. The wind is among the key disturbance agents $[4,5]$, accounting for about half of the recorded damage in European forests over the last two centuries [1]. In Northern Europe, such damage is expected to continue to rise [6,7] due to a projected increase in the frequency of strong westerly winds in autumn [8] combined with a shortened frozen soil period that enhances tree anchorage during this season $[9,10]$.

Post-disturbance salvage logging, i.e., removal of fallen and damaged trees, is conventionally done to mitigate economic loss after windthrow [11,12]. In some cases, it also helps to decrease the probability of a secondary disturbance $[13,14]$. Revenue from salvage logging is usually substantially lower than could be obtained from undamaged trees, as storms 
also affect forests that have not reached target cutting age/dimensions, and stem damage limits the possibility of obtaining the highest-graded assortments. Among the stem damage, breakage has the strongest negative economic effect on revenue [15]. Stem breakage occurs at the point where opposite sides of its cross-section experience compressive and tensile stresses that exceed the resistance of stem fibers [16]. An earlier study has suggested that bending stem with uniform wood properties subject outer wood layers to uniform stress, and the possibility of breakage is constant over the length of the stem [17]. However, in real trees, deviations of leaning or non-circular stems, crown shape asymmetries, stem defects, and other individual traits occur, which makes the presumption of uniform wood properties infeasible.

From a financial perspective, it is more favorable for a tree to break closer to a top because the monetary value of the stem is mainly determined by the recovery of the most valuable timber assortment (for aspen: Sawlogs) obtained from the stem base. Practical implications must link snapping height with easily detectable traits of the tree, such as these derived from height and diameter, or other traits included in forest inventory. While several studies have addressed tree- and stand-scale factors affecting the probability of stem breakage [18-21], factors that affect the height of stem breakage (snapping height) are seldom studied [22,23].

Historically, the main focus in Northern Europe has been put on the value of coniferous timber, though in hemiboreal forests, broadleaved species constitute a substantial part of growing stock. Studies of aspen timber, particularly, have been omitted under European conditions. However, such information might allow adjusting management measures to shape affecting factors, thus minimizing value loss. Considering that timber value is strongly linked to its quality and dimensions, assessment of recovered timber assortments provides information necessary to support salvage decisions that balance costs and returns from logging in post-disturbance stands. This encompasses an important component for evaluating/modeling possible storm outcomes and, hence, making forest policy decisions.

We hypothesized tree height and stem taper as the main tree-scale variables to explain the relative height of the breakage. In this study, we aimed to characterize the snapping height of European aspen and its effect on timber value loss.

\section{Materials and Methods}

\subsection{Study Area}

This study was conducted in hemiboreal forests (based on European forest types [24]) in Latvia $\left(55^{\circ} 60^{\prime}\right.$ to $58^{\circ} 10^{\prime} \mathrm{N}, 20^{\circ} 70^{\prime}$ to $28^{\circ} 50^{\prime} \mathrm{E}$ ), in aspen (Populus tremula L.) dominated and in mixed stands. According to the National Forest Inventory (NFI 2015-2019), forests cover about $52 \%$ (3.24 million ha) of the territory of Latvia, with a total growing stock of 681 million $\mathrm{m}^{3}$. Several large-scale windstorms have affected forests in the territory of our country, the most severe being in 1967 and 1969 when more than 26 million $\mathrm{m}^{3}$ of timber were damaged [25], and in 2005 when about 7.4 million $\mathrm{m}^{3}$ of timber was damaged [26]. However, even in the absence of a large-scale storm, wind damage is the main disturbance, accounting for $30 \%$ to $60 \%$ of annual sanitary clearcutting in the last years $[27,28]$.

\subsection{Data}

We used data available from NFI for three consecutive five-year re-measurement periods from 2004 to 2018, where each tree has a unique identification code (ID) that allows following tree development throughout the measuring periods. Measurements are done in clusters of four permanent circular sample plots that are systematically placed on a grid of $4 \times 4 \mathrm{~km}$ [29]. In each sample plot (area $\left.500 \mathrm{~m}^{2}\right)$, diameter at breast height (DBH) and height $(\mathrm{H})$ were measured for all trees with $\mathrm{DBH} \geq 14.1 \mathrm{~cm}$. A condition (live, broken, uprooted, or other) of each tree was noted. The age of the dominant canopy was measured, and forest type was noted according to Bušs [30].

First, we analyzed the occurrence of wind-induced stem breakage and uprooting for aspen from all NFI sample plots that contained any aspen tree. We used paired 
measurement periods (P1: 2004-2008 with 2009-2013, and P2: 2009-2013 with 2014-2018) to link individual tree data (tree and stand parameters) from the previous period with the observed tree condition in the following period. We included aspen trees from sample plots with the age of the dominant canopy $\geq 10$ years and density of the dominant canopy $\geq 100$ trees $\mathrm{ha}^{-1}$. The studied plots were characterized by the age of 10 to 171 years (Table 1), mainly growing on dry and drained mineral soils $(55.6 \%$ and $29.8 \%$ from all plots, respectively), dominated by aspen, birch, and spruce $(69.6 \%, 14.2 \%$, and $7.0 \%$, respectively). Only trees that were live snapped and uprooted (excluding trees that died due to other disturbances, e.g., cutting) at the latter paired measurement period (2009-2013 for P1 and 2014-2018 for P2) were used. In total, we used 7677 observations from 4636 aspen trees, collected in 941 sample plots (Figure 1).

Table 1. Characteristics of sample plots. Number of observations for categorical variables, mean \pm standard deviation (SD) for continuous variables. P1—a paired period of 2004-2008 and 2009-2013, P2-a paired period of 2009-2013 and 2014-2018.

\begin{tabular}{|c|c|c|c|c|}
\hline \multirow{2}{*}{ Stand Characteristics } & \multirow{2}{*}{ Description } & \multirow{2}{*}{ Classes/Range } & \multicolumn{2}{|c|}{ Number of Observations/Mean \pm SD } \\
\hline & & & P1 & P2 \\
\hline Age, years & $\begin{array}{l}\text { Age of the overstory } \\
\text { dominant species }\end{array}$ & 10-171 & $50.9 \pm 18.0$ & $52.8 \pm 19.7$ \\
\hline Height, m & $\begin{array}{l}\text { Height of the overstory } \\
\text { dominant species }\end{array}$ & $5.9-40.1$ & $24.9 \pm 5.1$ & $25.9 \pm 5.5$ \\
\hline $\mathrm{DBH}, \mathrm{cm}$ & $\begin{array}{c}\text { Diameter at breast height } \\
\text { of the overstory } \\
\text { dominant species }\end{array}$ & $6.9-74.3$ & $26.3 \pm 9.0$ & $27.6 \pm 10.0$ \\
\hline Volume, $\mathrm{m}^{3} \mathrm{ha}^{-1}$ & $\begin{array}{l}\text { The standing volume of the } \\
\text { dominant canopy }\end{array}$ & 5-1058 & $370 \pm 155$ & $386 \pm 168$ \\
\hline Density, trees ha ${ }^{-1}$ & $\begin{array}{l}\text { Number of trees of the } \\
\text { dominant canopy }\end{array}$ & $100-9020$ & $1306 \pm 1004$ & $1181 \pm 840$ \\
\hline Basal area, $\mathrm{m}^{2} \mathrm{ha}^{-1}$ & $\begin{array}{l}\text { Basal area of the } \\
\text { dominant canopy }\end{array}$ & $1-76$ & $32.9 \pm 10.3$ & $33.0 \pm 10.6$ \\
\hline \multirow{5}{*}{ Site type } & \multirow{5}{*}{$\begin{array}{l}\text { Site type groups, based on } \\
\text { the depth of the peat layer } \\
\text { and moisture regime }\end{array}$} & Dry mineral soil & 2221 & 2048 \\
\hline & & Wet mineral soil & 350 & 305 \\
\hline & & Peat soil & 36 & 73 \\
\hline & & Drained mineral soil & 1309 & 978 \\
\hline & & Drained peat soil & 196 & 161 \\
\hline \multirow{7}{*}{ Dominant species } & \multirow{7}{*}{$\begin{array}{l}\text { Overstory species with the } \\
\text { highest growing stock }\end{array}$} & Pine & 140 & 135 \\
\hline & & Spruce & 299 & 239 \\
\hline & & Birch & 560 & 533 \\
\hline & & Black alder & 82 & 58 \\
\hline & & Aspen & 2884 & 2461 \\
\hline & & Grey alder & 103 & 83 \\
\hline & & Other broadleaved species & 44 & 56 \\
\hline Sample size & Number of trees per plot & $1-54$ & $4.9 \pm 6.8$ & $4.6 \pm 6.0$ \\
\hline
\end{tabular}

Pine-Pinus sylvestris L., Spruce-Picea abies (L.) Karst., Birch—Betula pendula Roth. and B. pubescens Ehrh., Black alder-Alnus glutinosa (L.) Gaertn., Aspen—Populus tremula L., Grey alder-Alnus incana (L.) Moench. Other broadleaved species—Salix spp., Ulmus glabra Huds. and U. laevis Pall., Acer platanoides L., Tilia cordata Mill., Quercus robur L., Fraxinus excelsior L. 


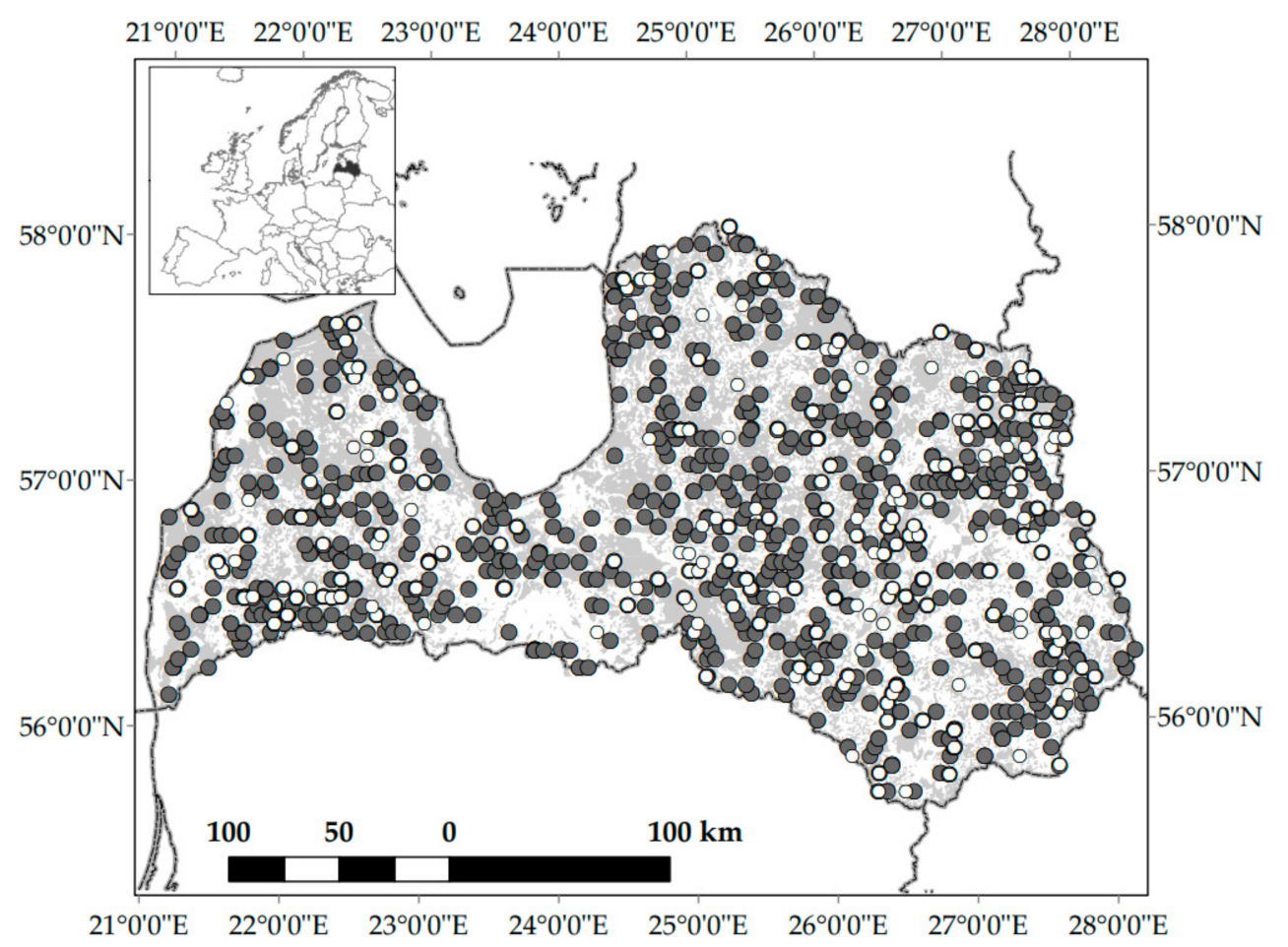

Figure 1. The location of the National Forest Inventory sample plots used for the analysis of windinduced damage occurrence (dark circles) and analysis of stem assortment recovery (clear circles). Grey background coloring indicates forest areas.

\subsection{Modeling of Snapping Height}

Factors affecting the relative height of stem breakage were analyzed by measuring the snapping height of snags and pairing these data with available parameters of the same tree from the previous NFI re-measuring period. Model parameters were selected based on possible impacting factors, i.e., with biological meaning. The data set included individual tree height and diameter, the height of the snag (snapping height), mean age, basal area, volume, and density of the dominant canopy, and the forest type. For each tree, we calculated the slenderness coefficient (height to $\mathrm{DBH}\left(\mathrm{HD}^{-1}\right)$ ratio), as it is commonly used to determine tree resistance to loading. However, smaller trees are found to have higher slenderness than taller, older trees when the competition is not a limiting factor [31,32], thus we also tested the effect of quadratic-height to $\mathrm{DBH}\left(\mathrm{H}^{2} \mathrm{D}^{-1}\right)$ ratio as a measure of tree slenderness that considers tree height. Relative snapping height was calculated as a ratio between snapping height and tree height and converted to a percentage. To test the effect of the forest type group, only forest types with the highest occurrence of aspen and a sufficient number of trees per each group were included: Dry mineral soils (no peat layer, rooting depth unsaturated with water) represented by Hylocomiosa and Oxalidosa forest types and drained mineral soils (peat depth $<20 \mathrm{~cm}$ ) represented by Myrtillosa mel. and Mercurialiosa mel. forest types. To be able to test the effect of site conditions, only data of trees on these site types were used, assembling in total 105 trees. Due to the relatively low number of observations and collinearity of several of the parameters, it was not possible to develop the most promising model by stepwise regression. Alternatively, we made three linear models including parameters of tree dimensions (height and age), its social status within the stand (slenderness coefficients), and site conditions (forest type as an indicator of soil fertility, moisture regime, and structure). The developed models included: (1) Tree height and $\mathrm{H}^{2} \mathrm{D}^{-1}$, (2) stand age and $\mathrm{HD}^{-1}$, and (3) tree height and forest type group. Variance inflation factors (VIF) analysis was performed for each of the three models, and in all cases, VIF values were below 1.5 , showing that there is no significant collinearity between the variables. Only in a few cases, there were more than one snapped tree per plot 
(stand), thus, no nested effect was applied. The selection of the best performing model was based on the comparison of the Akaike information criterion (AIC).

\subsection{Calculations of Timber Assortment Recovery}

The effect of snapping height on timber assortment recovery was based on data of 525 snags. Tree height was obtained from the studied stands, based on the mean tree height for the respective DBH. The assortment outcome was manually calculated for each sample tree using a bucking algorithm developed by Ozolins [33] and modified by J. Donis (unpublished). The modification was applied to calculate parameters of stem form equation: Gaffrey's generalized diameter-height regression [34] parameterized on NFI data was used instead of the default algorithm. The bucking algorithm is based on tree parameters $(\mathrm{H}$ and $\mathrm{DBH}$ ) and pre-defined timber assortments (Table 2), and it maximizes production of the most valuable assortment, i.e., sawlog production was prioritized where dimensions were sufficient, followed by pallet blocks (timber for pallet production), and technological wood. A section of stem at least one meter above and below the snapping height was counted as residual wood (based on the mean of measurements in the tree pulling tests, unpublished). The residual wood section was calculated longer if the length between the snapping point and top-end of the previous assortment was smaller than needed for the full length of assortment. Again, the stem part above the residual section was primarily used for the production of the most valuable assortment regarding stem diameter at a particular height. Two assortment outcomes of the broken trees were calculated: (1) Undamaged-based only on dimensions of the tree, (2) salvaged-considering the impact of snapping.

Table 2. Description and price of aspen timber assortments, applied from Joint Stock Company 'Latvia's State Forests'.

\begin{tabular}{|c|c|c|c|c|c|c|c|c|}
\hline \multirow{2}{*}{ Assortments } & \multicolumn{2}{|c|}{ Dimensions } & \multicolumn{6}{|c|}{ Price $^{a}$, EUR m ${ }^{-3}$} \\
\hline & Diameter ${ }^{\mathrm{c}}, \mathrm{cm}$ & Length, $\mathrm{m}$ & 2016 & 2017 & 2018 & 2019 & $2020^{b}$ & Mean \\
\hline Aspen sawlogs & $\geq 24.0$ & 2.4 & 38.71 & 39.67 & 47.65 & 51.74 & 49.77 & 45.51 \\
\hline Pallet blocks & $12.0-23.9$ & 2.4 & 32.68 & 30.64 & 39.78 & 40.75 & 33.98 & 35.57 \\
\hline Technological wood ${ }^{\mathrm{d}}$ & $5.0-11.9$ & 3.0 & 26.94 & 27.04 & 33.68 & 34.71 & 29.00 & 30.27 \\
\hline
\end{tabular}

${ }^{a}$ mean weighted price, ${ }^{b}$ calculated from the first and the second quarter, ${ }^{c}$ diameter at the narrowest end of the log, ${ }^{\mathrm{d}}$ comprised by two-thirds of technological wood and one-third of firewood.

Assortments and their prices were applied from Joint Stock Company 'Latvia's State Forests' (Table 2, [35]). Four assortments are available at the current timber market for aspen: Large-dimension sawn materials are used for sawlog production, whereas the small dimension, lower quality sawn material is used for pallet production (pallet blocks), and tops of the large logs are used as a technological wood and firewood. We integrated firewood under an assortment of technological wood, as they mainly differ by quality properties that were not possible to distinguish by available data. The price for this assortment was calculated, accounting for two-thirds of technological wood and one-third of firewood. The sensitivity of results to fluctuations in the timber market was reflected by three price levels: Average (mean of 2016-2020), minimum (the year 2016), and maximum (the year 2019). The total value of the tree was calculated as a sum of the volume of each assortment multiplied by its value for a particular price level. The residual wood did not contribute to the total tree volume.

We used a one-way analysis of variance, followed by Tukey's honest significance test to detect significant differences in DBH and height of undamaged, broken, and uprooted trees. A chi-squared test was used to assess differences in timber volume and timber value of assortments between salvaged and undamaged trees. Wilcoxon test was used to compare the mean volume per tree of a certain assortment between salvaged and undamaged trees. The relation between tree variables (DBH and snapping height) and value loss per tree and relative value loss, as well as the relation between a particular assortment volume 
loss and total tree value loss, was assessed by Pearson's correlation. Mean values $\pm 95 \%$ of confidence intervals are shown throughout the paper.

\section{Results}

Among the studied stands, $3.6 \%$ of trees (148 out of 4112 aspen tree) were wind damaged during the first paired period (P1: 2004-2008 and 2009-2013), and 3.4\% of trees (120 out of 3565 aspen tree) were wind damaged during the second paired period (P2: 2009-2013 and 2014-2018). Among the damaged trees, almost half ( $46.6 \%$ and $45.8 \%$, respectively) were broken. No statistically significant differences were found among the mean DBH of undamaged, broken, and uprooted trees: $28.2 \pm 0.2,29.3 \pm 2.1$, and $28.1 \pm 2.2 \mathrm{~cm}$, respectively. The mean height of broken trees was $27.3 \pm 0.9 \mathrm{~m}$, and it was significantly higher than the height of undamaged $(25.8 \pm 0.1 \mathrm{~m}, p=0.006)$ and uprooted trees $(25.3 \pm 0.9 \mathrm{~m}$, $p=0.005)$. Mean snapping height was $7.2 \pm 0.4 \mathrm{~m}$.

The tested models indicated tree height as the main explanatory variable for relative snapping height (Table 3), and higher trees had a lower point of the stem breakage (Figure 2a). The other significant factor was the forest type group, indicating that trees growing on dry mineral soils had lower relative snapping height than trees growing on drained mineral soils (Figure 2b). No significant influence on snapping height was detected for any of the tested tree slenderness ratios $\left(\mathrm{H}^{2} \mathrm{D}^{-1}\right.$ and $\left.\mathrm{HD}^{-1}\right)$ and stand age.

Table 3. Parameter and model estimates of the relative snapping height models.

\begin{tabular}{|c|c|c|c|c|c|c|c|c|}
\hline \multirow{2}{*}{ Model } & \multirow{2}{*}{$\begin{array}{c}\text { Explanatory } \\
\text { Variables }\end{array}$} & \multicolumn{4}{|c|}{ Parameter Estimates } & \multicolumn{3}{|c|}{ Model Estimates } \\
\hline & & Est. & $\mathrm{SE}$ & t-Value & $p$-Value & Adj. $R^{2}$ & AIC & $p$-Value \\
\hline \multirow{3}{*}{1} & Tree height & -1.42 & 0.42 & -3.37 & 0.001 & \multirow{3}{*}{0.090} & \multirow{3}{*}{939.1} & \multirow{3}{*}{0.003} \\
\hline & $\mathrm{H}^{2} \mathrm{D}^{-1}$ & 0.20 & 0.24 & 0.82 & 0.412 & & & \\
\hline & Intercept & 66.11 & 10.34 & 6.39 & $<0.001$ & & & \\
\hline \multirow{3}{*}{2} & Stand age & 0.01 & 0.12 & 0.10 & 0.918 & \multirow{3}{*}{-0.015} & \multirow{3}{*}{950.6} & \multirow{3}{*}{0.808} \\
\hline & $\mathrm{HD}^{-1}$ & 4.58 & 7.10 & 0.65 & 0.520 & & & \\
\hline & Intercept & 27.12 & 10.29 & 2.63 & 0.001 & & & \\
\hline \multirow{3}{*}{3} & Tree height & -1.30 & 0.36 & -3.62 & $<0.001$ & \multirow{3}{*}{0.131} & \multirow{3}{*}{934.3} & \multirow{3}{*}{$<0.001$} \\
\hline & Forest type group & -10.61 & 4.52 & -2.35 & 0.021 & & & \\
\hline & Intercept & 76.14 & 10.81 & 7.04 & $<0.001$ & & & \\
\hline
\end{tabular}

$\mathrm{H}^{2} \mathrm{D}^{-1}$ — tree quadratic-height to diameter-at-breast-height ratio, $\mathrm{HD}^{-1}$ — tree height to diameter-at-breast-height ratio, Est.—estimate, SE—standard error, Adj. $\mathrm{R}^{2}$ —adjusted R-squared, AIC—Akaike Information Criterion.
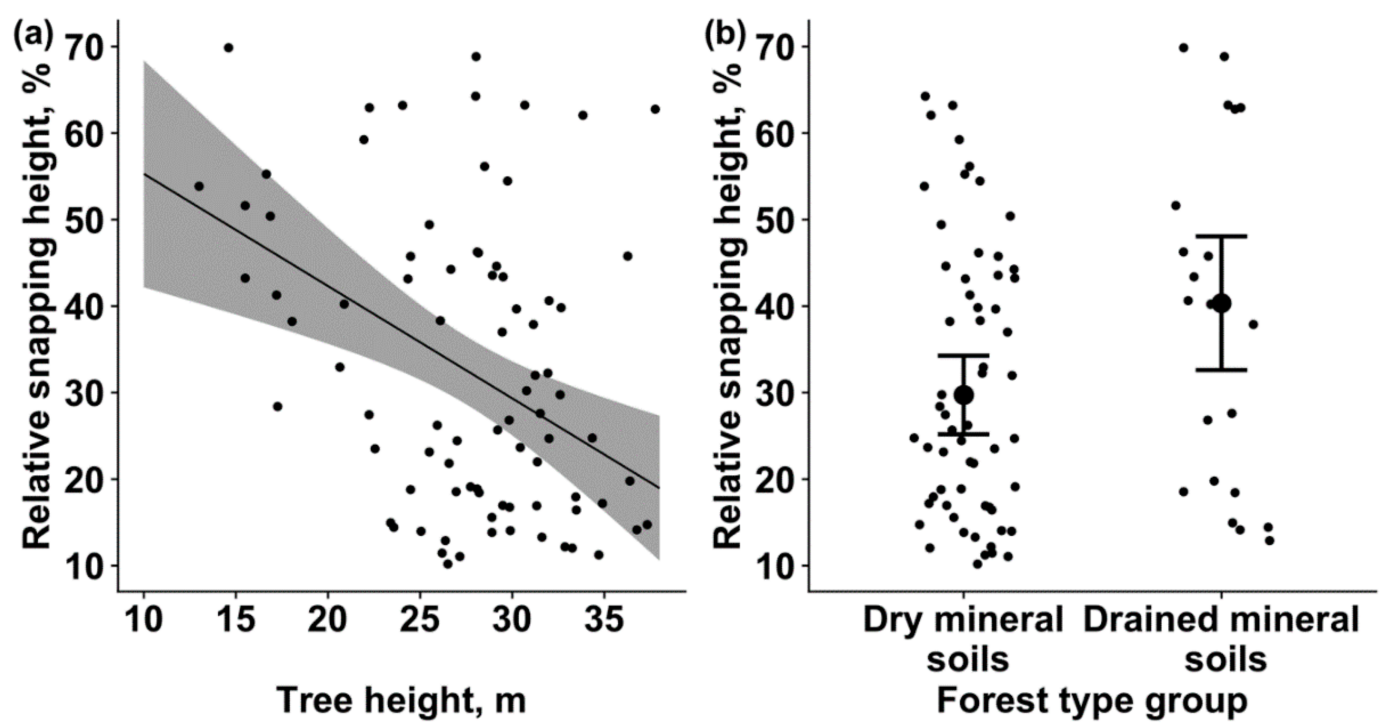

Figure 2. Relative snapping height in relation to tree height (a) and forest type group (b). The grey area (a) and error bars (b) represent $\pm 95 \%$ confidence interval. Dry—forest types on dry mineral soil, drained—forest types on drained mineral soil. 
Stem breakage reduced the volume of all assortments compared to the volume of undamaged trees ( $p=0.034$, Figure 3). For all assortments, the mean volume per tree significantly differed between salvaged and undamaged trees (all $p<0.001$ ). The volume reduction was $37.7 \%$ for sawlogs, $11.0 \%$ for pallet blocks, and $8.9 \%$ for technological wood, in total $24.7 \%$. The volume of residual wood (i.e., stem wood that did not qualify for any assortment type) comprised about one-third (34.0\%) of the total volume of salvaged trees and was more than double that of undamaged trees.

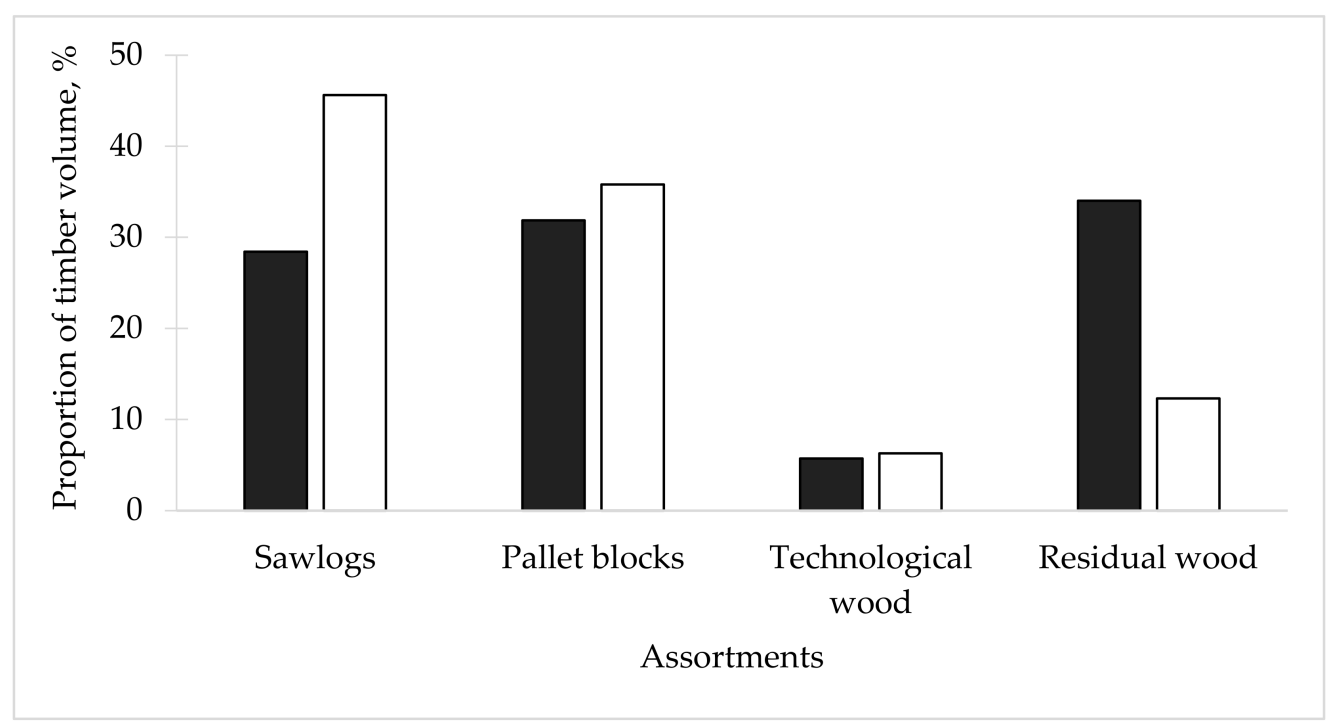

Figure 3. The proportion of assortment and residual wood volume for salvaged and undamaged trees $(n=525)$.

According to the bucking algorithm, theoretically, sawlogs could be obtained from undamaged trees with $\mathrm{DBH}$ at least $25 \mathrm{~cm}$ (242 trees out of the total 525). However, trees with DBH 25-27 cm tended to have a low snapping height (1.5 to $3.2 \mathrm{~m}$ ), hence, this assortment was produced only for trees with DBH at least $27 \mathrm{~cm}$ (Figure 4).

The total loss of a certain assortment volume was rare (Figure 4 ). In the analyzed sample, all assortment volume was reduced for 3.7\% of trees for sawlogs, $1.3 \%$ of trees for pallet blocks, and 3.6\% of trees for technological wood on average. The majority of trees $(90.1 \%)$ had reduced some volume of sawlogs. For pallet blocks and technological wood, no volume loss was found for $54.9 \%$ and $85.9 \%$ of trees, respectively.

The sawlog volume loss varied greatly along the DBH, with no clear tendencies. Volume loss of pallet blocks and technological wood also showed great variation, but larger values of the reduced timber volume were clustered for smaller diameter trees (Figure 4). The relative snapping height had a logarithmic relationship with the relative loss of sawlog and pallet block volume: Both showed a steep increase up to snapping height of $6 \mathrm{~m}$ and remained stable for trees with higher snapping height (Figure 4). No clear trends were found for technological wood.

Stem breakage significantly affected total timber value at all price levels (all $p<0.001$, Figure 5). Larger diameter trees had a higher value loss (at all price levels, $r=0.83$, $p<0.001$ ). However, the relative value loss (value loss divided by the value of undamaged tree) was rather similar regardless of tree DBH (among price levels $\mathrm{r}=0.18 \ldots 0.19, p<0.05$ ), and followed the same logarithmic trend as found for sawlog and pallet block volume loss. The relative value loss was strongly and significantly correlated with the relative volume loss of sawlog timber $(\mathrm{r}=0.72, p<0.01)$, whereas pallet block and technological wood volume showed weak but significant $(\mathrm{r}=0.44, p<0.001)$ and no link $(\mathrm{r}=-0.03, p>0.05)$ to relative value loss of total stem, respectively. 


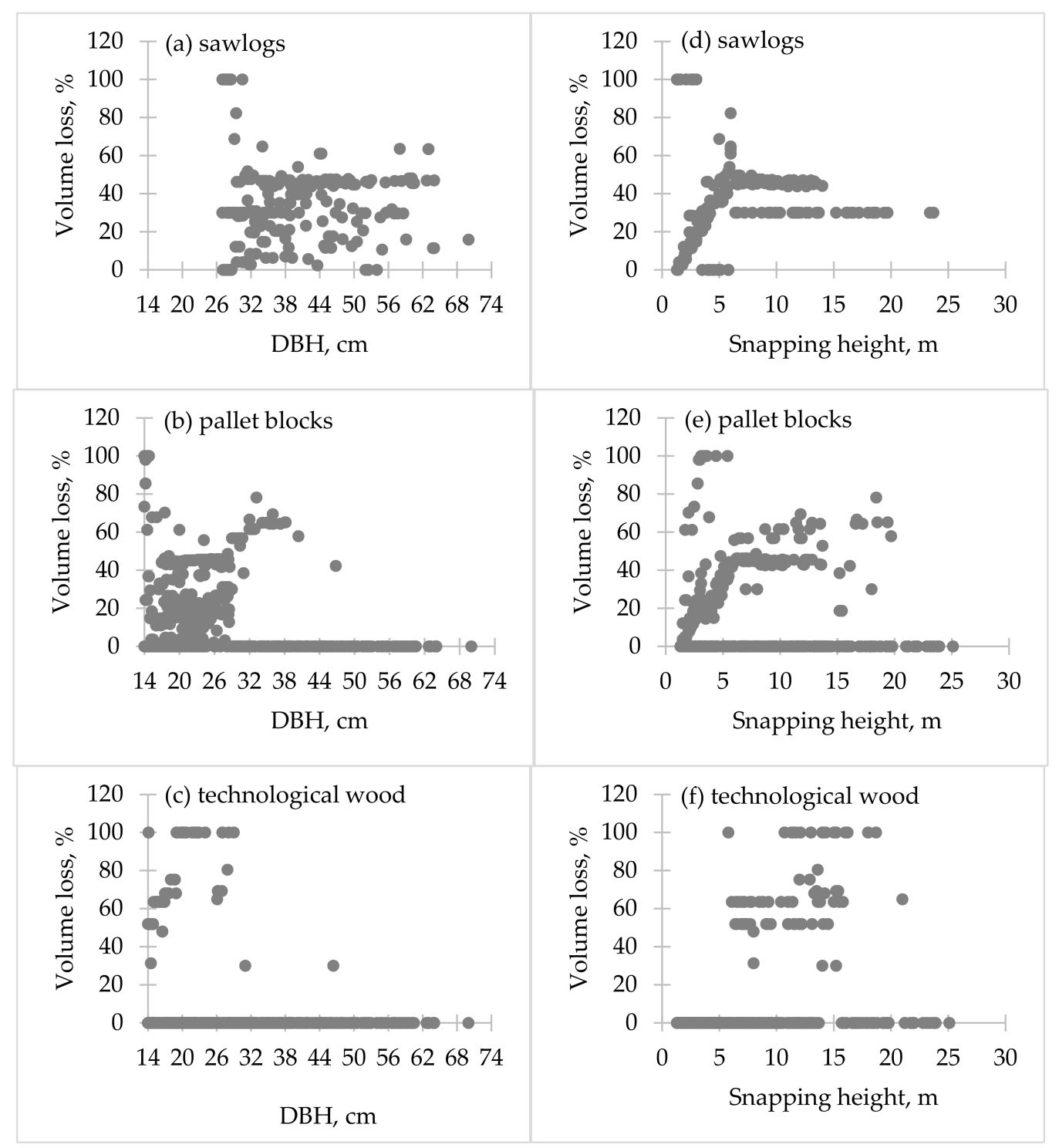

Figure 4. The relative volume loss of salvaged trees for $(\mathbf{a}, \mathbf{d})$ sawlogs $(n=242),(\mathbf{b}, \mathbf{e})$ pallet blocks $(n=525)$, and $(\mathbf{c}, \mathbf{f})$ technological wood $(n=525)$ in relation to tree diameter-at-breast-height $(\mathrm{DBH})$ classes (left side) and snapping height (right side).

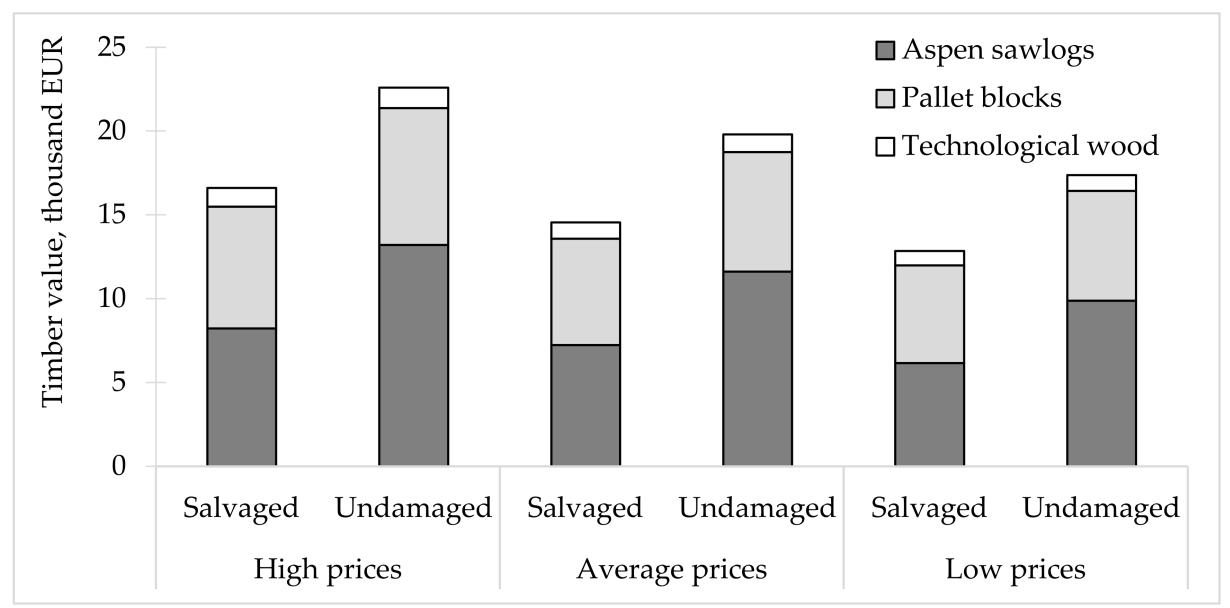

Figure 5. Timber value for salvaged and undamaged timber $(n=525)$ according to high (the year 2019), average (mean for 2016-2019), and low (the year 2016) prices. 
The assortment prices (obtained from the actual market) fluctuated among the years, with the highest difference of $25.2 \%$ for sawlogs, $19.8 \%$ for pallet blocks, and $22.4 \%$ for technological wood (Table 2). Price fluctuations significantly affected the calculated timber value of assortments for undamaged trees $(p=0.004)$, as well as for salvaged trees $(p=0.022)$. Total timber value under different price levels fluctuated by $0.4 \%$, while value reduction for each assortment was constant regardless of price level: $37.7 \%$ for sawlogs, $11.0 \%$ for pallet blocks, and 8.9\% for technological wood (Figure 5).

\section{Discussion}

Stem breakage occurred for almost half of the wind damaged trees studied in a period of 15 years. These results predominantly refer to the intensity of a gap disturbance dynamics, as the studied sample plots included any windblown sites, and the type of wind-induced damage is primarily affected by wind speed [36]. Under intense disturbance, the proportion of broken trees might be different, as indicated by a slightly lower proportion ( $41 \%$ of damaged trees) of broken aspen in a study of two successive severe windstorms [37].

The factors affecting the possibility of a stem breakage are often studied after windinduced damage in forests (e.g., $[18,19,38]$ ), whereas the height of this breakage along the stem is generally omitted in studies. The negative effect of stem breakage on assortment outcomes might be reduced if management actions could alter the snapping height. Our results suggest that the relative height of the stem breakage could be best explained by a linear model, including explanatory variables tree height and forest type. Both of these parameters and the intercept were significant, however, the model explained a rather small part of the variation of the snapping height. The significant effect of forest type on lower relative snapping height of aspen growing on dry mineral soils than for aspen growing on drained mineral soils is hard to explain but presumably might be related to soil composition. Both of these forest type groups have unsaturated soil at the rooting depth, but drained soils typically comprise an upper peat layer that allows more flexible swaying, i.e., more dynamic response to wind gusts [39].

Tree height showed a significant effect on two of the tested models. Our results indicate that broken trees were significantly higher than undamaged and uprooted trees and are in line with several studies [40-42] that have linked vulnerability to damage with increased tree height. Other studies, however, have argued that for a fixed taper, increasing tree height has almost no effect on the critical wind speed for overturning or damage [36,40]. Thus, increased damage could also be related to other tree characteristics that are changing along with the tree height.

The stand age showed a non-significant effect on relative snapping height, likely because the age of the aspen trees might differ from the age of the dominant canopy, especially in mixed-stands. However, higher trees are presumably to be older, and have age-related wood quality characteristics that might affect the relative snapping height but were not possible to be included in our models. Older trees are more likely to have stem defects (e.g., branch nodes, wounds), and aspen is particularly prone to heart rot caused by Phellinus tremulae (Bond.) Bond. and Borisov. [43] and galleries at the tree stump level created by wood borer Saperda carcharias L. [44]. Such internal stem and root defects decrease structural resistance and might serve as a snapping point, partly explaining our observed negative relation between relative snapping height and tree height. Indeed, studies have shown that borer activity is linked to the breakage of the damaged stem segments of Populus clones [45]. Prior stem damage is also found to lower snapping height [23] and to decrease necessary loading for stem breakage [46], meaning that internally damaged trees are broken more easily.

Suppressed, slender trees are less stable than dominant trees [39]. Additionally, studies of freely growing trees have found smaller trees to be more slender than larger trees [31,32], indicating that slenderness is also related to tree development and not exclusively to its social status within a stand or stand density. For this reason, we also tested the slenderness 
coefficient with a higher weight on tree height. However, both our tested slenderness ratios $\left(\mathrm{HD}^{-1}\right.$ and $\left.\mathrm{H}^{2} \mathrm{D}^{-1}\right)$ did not reveal a significant effect on the relative snapping height.

Stem breakage had a substantial negative effect on assortment production, with the largest impact on sawlogs. Our calculated total loss of volume was close ( $25 \%$ vs. $27 \%)$ to that observed after a catastrophic storm in Ireland [22]. We found no trend between snapping height of a particular diameter and sawlog outcome, which could largely be a consequence for a small number of trees per each group combined with the relatively large effect of each produced log, e.g., in a case when tree dimensions are sufficient to obtain two sawlogs, snapping might reduce sawlog outcome by half or even all log volume that could be produced from an undamaged tree.

The wind had damaged trees younger and with smaller DBH than would be harvested according to national legislation in undamaged conditions, i.e., trees that have not reached potential dimensions for highest-priced assortments. Although harvesting younger trees could result in less residue wood due to a lower incidence of rot, smaller dimension trees contribute less to the most valuable assortment (sawlog) production. The studied sites did not include any windthrown stands, hence, the loss of assortments would be smaller than under intense disturbance. In a catastrophic case, as much as $60 \%$ to $85 \%$ of the total harvested volume could be suitable only for chip production [47]. Moreover, the high loss of potential income is accompanied by increased harvesting costs that are higher than for undisturbed stands [48]. For a period from 2000 to 2017 in Sweden, the difference in salvaged and ordinary thinning costs was $21 \%$, and for salvaged and ordinary final felling $64 \%$ [49]. In Finland, such differences were 35-64\% for cutting stems with a volume of 0.3 to $1.5 \mathrm{~m}^{3}$ and $10-30 \%$ for logging windfalls [48].

Our calculations showed significant value reduction due to stem breakage. These calculations were based on ordinary market prices, whereas large scale forest disturbances cause timber markets to decrease prices due to a sudden increase in the supply of timber entering the market [12]. For example, after a storm Gudrun in 2005, prices in Sweden dropped on average by $37 \%$ for spruce sawlogs and by $24 \%$ for pine sawlogs, in comparison to prices a year before the storm [40]. However, while logging of a small scale (gap) disturbance might be decided based on economic calculations, salvage logging after a standreplacing storm in managed forests might be inevitable to promote stand regeneration and to minimize loss of land value, even if these operations are not profitable in the short term.

\section{Conclusions}

Stem breakage has a substantial negative effect on sawlog volume production that, in turn, reduces the monetary value of the whole stem. The negative effect of stem breakage is most pronounced for trees whose dimensions are potentially suitable for the production of only one sawlog. Breakage closer to the stem base has a highly variating effect on sawlog volume reduction, whereas breakage higher than $6 \mathrm{~m}$ in all cases reduces sawlog volume by $30 \%$ to $50 \%$. Quantitative estimates of the wind impact on assortment structure in salvage logging can be used in post-storm harvest planning as well as modeling of long-term influence of changes in storm frequency and/or intensity on the financial and economic value of forests.

Author Contributions: Conceptualization, Ā.J. and L.Č.; methodology, G.̌̌., L.L. and Ā.J.; formal analysis, D.E. and L.Č.; data curation, G.Š. and S.Š.; writing-original draft preparation, S.Š. and L.Č.; writing — review and editing, L.L. and Ā.J.; project administration, Â.J. All authors have read and agreed to the published version of the manuscript.

Funding: The study was funded by ERDF project "Birch and aspen stand management decision support tool for reduction of wind damages" (No. 1.1.1.1/18/A/134).

Institutional Review Board Statement: Not applicable.

Informed Consent Statement: Not applicable.

Data Availability Statement: The data presented in this study are available on request from the corresponding author. The data are not publicly available due to policy of the institute. 
Acknowledgments: Authors appreciate the work of researcher Janis Donis in upgrading the model for assortment calculation as well as input of anonymous reviewer that helped to improve the manuscript.

Conflicts of Interest: The authors declare no conflict of interest.

\section{References}

1. Schelhaas, M.J.; Nabuurs, G.J.; Schuck, A. Natural disturbances in the European forests in the 19th and 20th centuries. Glob. Chang. Biol. 2003, 9, 1620-1633. [CrossRef]

2. Gardiner, B.; Schuck, A.; Schelhaas, M.-J.; Orazio, C.; Blennow, K.; Nicoll, B. Living with Storm Damage to Forests; European Forest Institute: Joensuu, Finland, 2013.

3. Donis, J.; Saleniece, R.; Krisans, O.; Dubrovskis, E.; Kitenberga, M.; Jansons, A. A financial assessment of windstorm risks for scots pine stands in hemiboreal forests. Forests 2020, 11, 566. [CrossRef]

4. Seidl, R.; Thom, D.; Kautz, M.; Martin-Benito, D.; Peltoniemi, M.; Vacchiano, G.; Wild, J.; Ascoli, D.; Petr, M.; Honkaniemi, J.; et al. Forest disturbances under climate change. Nat. Clim. Chang. 2017, 7, 395-402. [CrossRef]

5. Forzieri, G.; Pecchi, M.; Girardello, M.; Mauri, A.; Klaus, M.; Nikolov, C.; Rüetschi, M.; Gardiner, B.; Tomastik, J.; Small, D.; et al. A spatially explicit database of wind disturbances in European forests over the period 2000-2018. Earth Syst. Sci. Data 2020, 12, 257-276. [CrossRef]

6. $\quad$ Leckebusch, G.C.; Koffi, B.; Ulbrich, U.; Pinto, J.G.; Spangehl, T.; Zacharias, S. Analysis of frequency and intensity of European.pdf. Clim. Res. 2006, 31, 59-74. [CrossRef]

7. Seidl, R.; Schelhaas, M.; Rammer, W.; Verkerk, P.J. Increasing forest disturbances in Europe and their impact on carbon storage. Nat. Clim. Chang. 2014, 4, 806-810. [CrossRef] [PubMed]

8. Ruosteenoja, K.; Vihma, T.; Venäläinen, A. Projected changes in european and north atlantic seasonal wind climate derived from CMIP5 simulations. J. Clim. 2019, 32, 6467-6490. [CrossRef]

9. Kellomäki, S.; Maajärvi, M.; Strandman, H.; Kilpeläinen, A.; Peltola, H. Model computations on the climate change effects on snow cover, soil moisture and soil frost in the boreal conditions over Finland. Silva. Fenn. 2010, 44, 213-233. [CrossRef]

10. Laapas, M.; Lehtonen, I.; Venäläinen, A.; Peltola, H. The 10-year return levels of maximum wind speeds under frozen and unfrozen soil forest conditions. Climate 2019, 7, 62. [CrossRef]

11. Leverkus, A.B.; Lindenmayer, D.B.; Thorn, S.; Gustafsson, L. Salvage logging in the world's forests: Interactions between natural disturbance and logging need recognition. Glob. Ecol. Biogeogr. 2018, 27, 1140-1154. [CrossRef]

12. Prestemon, J.P.; Holmes, T.P. Timber Salvage Economics. In The Economics of Forest Disturbances; Holmes, T.P., Prestemon, J.P., Abt, K.L., Eds.; Springer Science + Business Media: Dordrecht, The Netherlands, 2008; pp. 167-190.

13. Stadelmann, G.; Bugmann, H.; Meier, F.; Wermelinger, B.; Bigler, C. Effects of salvage logging and sanitation felling on bark beetle (Ips typographus L.) infestations. For. Ecol. Manag. 2013, 305, 273-281. [CrossRef]

14. Økland, B.; Nikolov, C.; Krokene, P.; Vakula, J. Transition from windfall-to patch-driven outbreak dynamics of the spruce bark beetle Ips typographus. For. Ecol. Manag. 2016, 363, 63-73. [CrossRef]

15. Gardiner, B.; Peltola, H.; Kellomäki, S. Comparison of two models for predicting the critical wind speeds required to damage coniferous trees. Ecol. Modell. 2000, 129, 1-23. [CrossRef]

16. James, K. Dynamic loading of trees. J. Arboric. 2003, 29, 165-171.

17. Petty, J.A.; Worrell, R. Stability of coniferous tree stems in relation to damage by snow. Forestry 1981, 54, 115-128. [CrossRef]

18. Ancelin, P.; Courbaud, B.; Fourcaud, T. Development of an individual tree-based mechanical model to predict wind damage within forest stands. For. Ecol. Manag. 2004, 203, 101-121. [CrossRef]

19. Dunham, R.A.; Cameron, A.D. Crown, stem and wood properties of wind-damaged and undamaged Sitka spruce. For. Ecol. Manag. 2000, 135, 73-81. [CrossRef]

20. Nishimura, T.B. Tree characteristics related to stem breakage of Picea glehnii and Abies sachalinensis. For. Ecol. Manag. 2005, 215, 295-306. [CrossRef]

21. Wallentin, C.; Nilsson, U. Storm and snow damage in a Norway spruce thinning experiment in southern Sweden. Forestry 2014, 87, 229-238. [CrossRef]

22. Nieuwenhuis, M.; Fitzpatrick, P.J. An assessment of stem breakage and the reduction in timber volume and value recovery resulting from a catastrophic storm: An irish case study. Forestry 2002, 75, 513-523. [CrossRef]

23. Snepsts, G.; Kitenberga, M.; Elferts, D.; Donis, J.; Jansons, A. Stem damage modifies the impact of wind on Norway Spruces. Forests 2020, 11. [CrossRef]

24. European Environment Agency. European Forest Types. Categories and Types for Sustainable Forest Management Reporting and Policy; Technical Report; European Environment Agency: Copenhagen, Denmark, 2007.

25. Ērglis, D. 1967. un 1969. gadu vētru sekas Latvijas PSR valsts mežos [Windstorm damage in 1967 and 1969 in forests of Latvian SSR]. Mežsaimniecība un Mežrūpniecība 1977, 4, 23-34.

26. Valsts meža dienests. 2006. Gada Publiskais Pārskats; Annual report 2006; VMD: Riga, Latvia, 2007.

27. Valsts meža Dienests. 2017. gada publiskais pārskats; Annual report 2017; VMD: Riga, Latvia, 2018.

28. Valsts meža dienests. 2019. gada publiskais pārskats; Annual report 2019; VMD: Riga, Latvia, 2020. 
29. Jansons, J.; Līcīte, I. Latvia. In National Forest Inventories: Pathways for Common Reporting; Tomppo, E., Gschwantner, T., Lawrence, M., McRoberts, R.E., Eds.; Springer: Dordrecht, The Netherlands, 2010; pp. 341-350.

30. Bušs, K. Forest ecosystem classification in Latvia. Proc. Latv. Acad. Sci. Sect. B Nat. Exact Appl. Sci. 1997, 51, $204-218$.

31. Rust, S. Analysis of regional variation of height growth and slenderness in populations of six urban tree species using a quantile regression approach. Urban. For. Urban. Green. 2014, 13, 336-343. [CrossRef]

32. Grabosky, J.; Bassuk, N. Seventeen years' growth of street trees in structural soil compared with a tree lawn in New York City. Urban. For. Urban. Green. 2016, 16, 103-109. [CrossRef]

33. Ozolins, R. Forest stand assortment structure analysis using mathematical modelling. Metsanduslikud Uurim. For. Stud. 2002, $37,33-42$.

34. Von Gadow, K.; Hui, G. Modelling Forest Development; Forestry Sciences; Springer: Dordrecht, The Netherlands, 1999 ; Volume 57.

35. Latvijas Valsts meži. Joint Stock Company 'Latvia's State Forests' Apalı Kokmateriālu Cenas. Round Assortment Prices. Available online: https:/ / www.lvm.lv/biznesa-partneriem/produkti/koksnes-produkti/fakti-un-dati (accessed on 13 November 2020).

36. Peltola, H.; Kellomäki, S.; Väisänen, H.; Ikonen, V.P. A mechanistic model for assessing the risk of wind and snow damage to single trees and stands of Scots pine, Norway spruce, and birch. Can. J. For. Res. 1999, 29, 647-661. [CrossRef]

37. Ilisson, T.; Metslaid, M.; Vodde, F.; Jõgiste, K.; Kurm, M. Storm disturbance in forest ecosystems in Estonia. Scand. J. For. Res. 2005, 20, 88-93. [CrossRef]

38. Peltola, H.; Kellomäaki, S. A mechanistic model for calculating windthrow and stem breakage of Scots Pine at stand adge. Silva. Fenn. 1993, 2, 99-111.

39. Sellier, D.; Fourcaud, T. Crown structure and wood properties:Influence on tree sway and response to high winds. Am. J. Bot. 2009, 96, 885-896. [CrossRef]

40. Gardiner, B.; Blennow, K.; Carnus, J.; Fleischer, P.; Ingemarson, F.; Landmann, G.; Lindner, M.; Marzano, M.; Nicoll, B.; Orazio, C.; et al. Destructive Storms in European Forests: Past and Forthcoming Impacts; European Forest Institute: Joensuu, Finland, 2010.

41. King, D.A. Tree form, height growth, and susceptibility to wind damage in Acer saccharum. Ecology 1986, 67, 980-990. [CrossRef]

42. Cremer, K.; Borough, C.; Mckinnell, F.; Carter, A. Effects of stocking and thinning on wind damage in plantations. N. Z. J. For. Sci. For. Sci. 1982, 12, 244-268.

43. Lõhmus, A. Aspen-inhabiting aphyllophoroid fungi in a managed forest landscape in Estonia. Scand. J. For. Res. 2011, 26, 212-220. [CrossRef]

44. Zeps, M.; Senhofa, S.; Zadina, M.; Neimane, U.; Jansons, A. Stem damages caused by heart rot and large poplar borer on hybrid and European aspen. For. Stud. 2017, 66, 21-26. [CrossRef]

45. Debell, D.S.; Harrington, C.A.; Clendenen, G.W.; Zasada, J.C. Tree growth and stand development of four Populus clones in large monoclonal plots. New For. 1997, 14, 1-18. [CrossRef]

46. Krisans, O.; Matisons, R.; Rust, S.; Burnevica, N.; Bruna, L.; Elferts, D.; Kalvane, L.; Jansons, A. Presence of root rot reduces stability of Norway spruce (Picea abies): Results of static pulling tests in Latvia. Forests 2020, 11, 416. [CrossRef]

47. Magagnotti, N.; Picchi, G.; Spinelli, R. A versatile machine system for salvaging small-scale forest windthrow. Biosyst. Eng. 2013, 115, 381-388. [CrossRef]

48. Kärhä, K.; Anttonen, T.; Poikela, A.; Palander, T.; Laurén, A.; Peltola, H.; Nuutinen, Y. Evaluation of salvage logging productivity and costs in windthrown Norway spruce-dominated forests. Forests 2018, 9. [CrossRef]

49. Eliasson, L.; Manner, J.; Thor, M. Costs for thinning and final felling operations in Sweden, 2000-2017. Scand. J. For. Res. 2019, 34, 627-634. [CrossRef] 